[Note]

\title{
Color Degradation of Lubricating Base Oil Fraction Induced by Sunlight Irradiation
}

\author{
Takayoshi SHIndo*, Eiji HoRIBE, Shigeaki KitabaYaSHI, and Sentaro Ozawa \\ Dept. of Materials-process Engineering \& Applied Chemistry for Environments, Faculty of Engineering and Resource Science \\ Akita University, 1-1 Tegata gakuen-cho, Akita 010-8502, JAPAN
}

(Received July 15, 1998)

\begin{abstract}
The behavior of color degradation of lubricating base oil in sunlight was investigated at ambient temperature, using UV-vis, FT-IR and fluorescence spectroscopy. Color of the oils turned from pale yellow to dark brown, and the amount of sediments formed increased with increasing sunlight irradiation. The color change was different, depending on the season of irradiation and/or the characteristics of sunlight and ambient temperature. The intensity of fluorescence emission spectra of the irradiated oil decreased in comparison with that of the original oil, indicating that those having emission of fluorescence spectra, and polynuclear aromatic compounds with three to five fused-ring cause color degradation. The sediments formed during irradiation comprised mainly aromatic compounds with carbonyl, carboxyl, and hydroxyl groups. Neither a significant change in color nor formation of sediments was detected in the degassed oil, but change in color and formation of sediments were observed in the original oil. It may therefore be concluded that both dissolved oxygen and the polynuclear aromatics in oil are indispensable for the color degradation induced by photo-irradiation.
\end{abstract}

\section{Introduction}

Color and its stability to light are of practical importance for lubricating oils such as spindle oil and process oil used in food, paper, and textile industries ${ }^{1)}$. It is not an exaggerated statement to make that one of the main purposes of refining petroleum products is to improve the color and stability of the refined products. Sulfuric acid and clay treating processes were traditionally used to improve color and stability of the petroleum products; but, hydrofinishing processes have recently been adopted for this purpose ${ }^{2), 3)}$. However, the oil obtained by traditional processes and by hydrofinishing process are quite different. The traditional processes effectively removed polar materials such as oxygenand nitrogen-containing compounds, while the hydrofinishing process is efficient and effective for desulfurization and/or denitrogenation ${ }^{4)}$. Although the hydrofinishing process has the advantage of not requiring disposal of waste acids and clays, a process such as clay treatment is still needed to produce highly stable insulating oils.

More recently, hydrotreating of lubricating oil stocks has been developed in place of solvent refining, which had been one of the main processes to remove aromatics and resins ${ }^{2), 3)}$. It is generally known that severe reaction conditions are needed for deep desulfurization or for deep denitrogenation of petroleum fractions ${ }^{5)}$,

* To whom correspondence should be addressed. and it is also known that color and stability of such severely hydrotreated oils are rarely improved by clay treating ${ }^{4}$. A severe hydrotreating of oils frequently leads to the formation of polynuclear aromatic compounds; therefore, it is quite possible to presume such compounds cause color degradation and/or color instability of the oils ${ }^{6)}$. In this paper, the behavior of color degradation of a lubricating base oil in sunlight is investigated and the materials formed by degradation are analyzed.

\section{Experimental}

\section{1. Sample}

The oil sample used in this study was a lubricating base oil, supplied by Funakawa Refinery, Japan Energy Corporation. It was hydrogenated, followed by dewaxing. Some relevant data on the sample oil supplied are presented in Table $\mathbf{1}$.

\section{2. Irradiation of Sample Oil with Sunlight}

The sample oil contained in a bottle of $c a .50 \mathrm{~cm}^{3}$ inner volume made of Pyrex glass with $2 \mathrm{~mm}$ wall thickness was irradiated by sunlight at ambient temperature. The value of global solar radiation was estimated using a Gorczynski type pyranometer installed in the meteorological observatory in Akita. The color degradation of the oil due to sunlight irradiation was evaluated by transmittance at $440 \mathrm{~nm}$, using the UV-vis spectrophotometer JASCO UNIDEC-210. Values observed were normalized with respect to the starting oil as 
Table 1 Characteristics of the Lubricating Base Oil Used in this Study

\begin{tabular}{|c|c|c|}
\hline \multicolumn{2}{|l|}{ Density, $\mathrm{d}_{4}^{20}$} & 0.8220 \\
\hline \multicolumn{2}{|l|}{ ASTM color } & L 1.0 \\
\hline \multicolumn{3}{|l|}{ Kinematic viscosity } \\
\hline (at $40^{\circ} \mathrm{C}$ ) & & 19.6 \\
\hline \multirow{2}{*}{\multicolumn{2}{|c|}{$\begin{array}{l}\left.\text { (at } 100^{\circ} \mathrm{C}\right) \\
\text { Viscosity index }\end{array}$}} & 4.48 \\
\hline & & 146 \\
\hline \multirow{2}{*}{\multicolumn{2}{|c|}{$\begin{array}{l}\text { Total acid number } \\
\text { Refractive index, } n_{20}^{D}\end{array}$}} & 0.02 \\
\hline & & 1.4581 \\
\hline \multicolumn{3}{|l|}{ n-d-M Ring analysis } \\
\hline \multicolumn{2}{|l|}{$\mathrm{M}$} & 418 \\
\hline $\mathrm{C}_{\mathrm{A}}$ & [\%] & 2.0 \\
\hline $\mathrm{C}_{\mathrm{N}}$ & [\%] & 2.2 \\
\hline$C_{p}$ & [\%] & 95.8 \\
\hline \multicolumn{2}{|l|}{$\mathrm{R}_{\mathrm{A}}$} & 0.10 \\
\hline \multicolumn{2}{|l|}{$\mathrm{R}_{\mathrm{N}}$} & 0.19 \\
\hline \multicolumn{3}{|l|}{ Column chromatography } \\
\hline Saturates & wt $\%]$ & 98.2 \\
\hline Aromatics & wt $\%]$ & 1.6 \\
\hline Resins & wt $\%]$ & 0.2 \\
\hline \multicolumn{3}{|l|}{ Distillation behavior } \\
\hline Initial boiling point & {$\left[{ }^{\circ} \mathrm{C}\right]$} & 318.8 \\
\hline Mid boiling point & {$\left[{ }^{\circ} \mathrm{C}\right]$} & 444.6 \\
\hline End point & {$\left[{ }^{\circ} \mathrm{C}\right]$} & 546.3 \\
\hline
\end{tabular}

$100 \%$. The amount of insoluble materials formed during irradiation was determined by measuring the weight of sediments separated from the sample solution by filtration using a membrane filter of $0.8 \mu \mathrm{m}$ pore diameter made of poly-tetrafluoroethylene.

\section{3. Analyses}

IR spectra of sediments formed during sunlight irradiation were measured by FT-IR spectroscopy using a Perkin Elmer 1600 instrument, and fluorescence emission spectra of the sample oils before and after irradiation were measured using a HITACHI F-2000 Fluorescence photo spectrometer.

\section{Results and Discussion}

\section{1. Color Degradation}

Color of the starting oil was pale yellow, and it gradually changed to dark yellow. Some insoluble materials suspended in the oil were detected from early stages of sunlight irradiation. The amount of insolubles increased with the period of sunlight irradiation, and color of the sample finally changed to dark brown, as shown in Fig. 1.

\section{2. Relation between Change in Color and Ambi- ent Temperature}

In the summer season, the value of transmittance of the sample oil at $440 \mathrm{~nm}$ decreased rapidly to $17 \%$ when the global solar radiation reached $c a .100 \mathrm{MJ} / \mathrm{m}^{2}$ after which it decreased gradually. The change in transmittance was much slower overall in winter as shown in Fig. 2. Regardless, in both seasons, the amount of

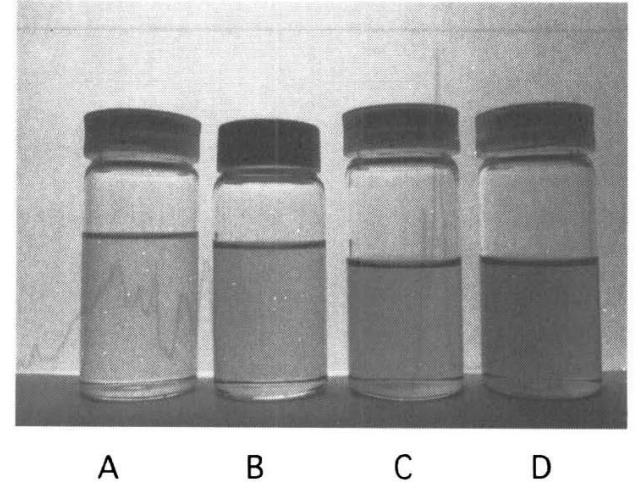

A: Original sample (before irradiation); B: Sunlight irradiation (102 $\mathrm{MJ} \mathrm{m}^{-2}$ ), after removing sediments; C: Sunlight irradiation (120 $\mathrm{MJ} \mathrm{m}^{-2}$ ), after removing sediments; D: Sunlight irradiation $\left(156 \mathrm{MJ} \mathrm{m}^{-2}\right)$, after removing sediments.

Fig. 1 Change in Color of Oil Samples with Sunlight Irradiation

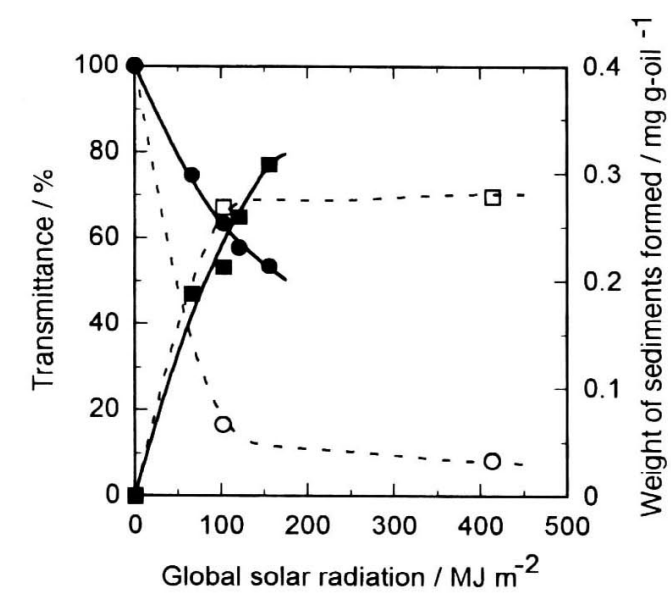

Transmittance: $\bigcirc$ summer, winter.

Amount of sediments: $\square$ summer, $\square$ winter.

Fig. 2 Transmittance of the Lubricating Base Oil Sample and Amount of Sediments Formed in it during Sunlight Irradiation

insoluble materials increased rapidly in the initial stage of irradiation. In summer the levels reached $0.27 \mathrm{mg} / \mathrm{g}$ oil at $100 \mathrm{MJ} / \mathrm{m}^{2}$ irradiation, and increased very slowly thereafter. Likewise in winter, the levels increased, however slightly more slowly. These results show that the behavior of color change with sunlight irradiation was different in summer and winter, suggesting that characteristics of sunlight, (i.e. wavelength, intensity distribution of sunlight) and the temperature during irradiation strongly affected the rate of color degradation of lubricant base oils. 


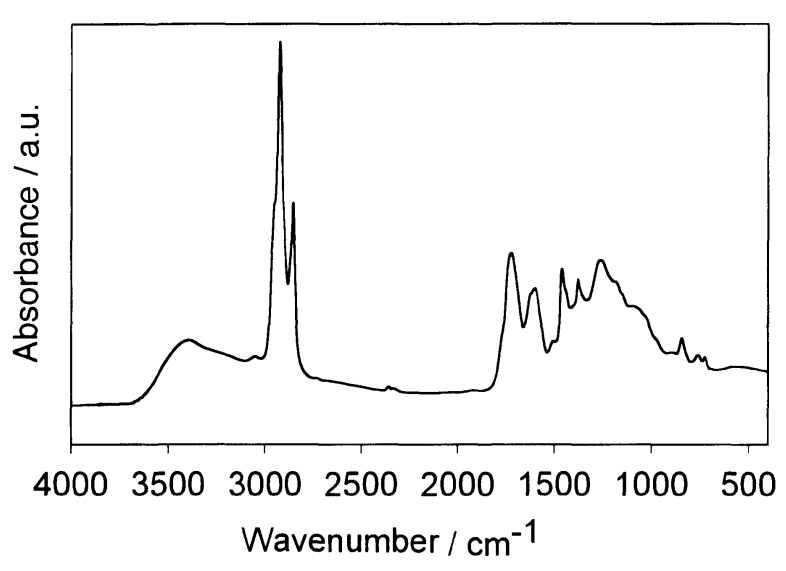

Global solar radiation (102 $\mathrm{MJ} \mathrm{m}^{-2}$ in summer).

Fig. 3 FT-IR Spectrum of Sediments Formed during Sunlight Irradiation

\section{3. Causes of Color Degradation}

\section{3. 1. Sediments Formed during Sunlight Irradi-} ation

Figure 3 shows an example of IR spectrum of the sediments. Bands around $3000 \mathrm{~cm}^{-1}$, and those in the $900-700 \mathrm{~cm}^{-1}$ region were assigned to stretching and to bending vibrations of the $\mathrm{C}-\mathrm{H}$ groups of aromatic compounds, respectively ${ }^{7), 8}$. The absorption peak at 1700 $\mathrm{cm}^{-1}$ and the broad bands at $1300-1200 \mathrm{~cm}^{-1}$ were associated with the $\mathrm{C}=\mathrm{O}$ stretching vibrations and $\mathrm{C}-\mathrm{O}$ bonds, respectively ${ }^{7,8)}$. The peak at $1600 \mathrm{~cm}^{-1}$ was assigned to the $\mathrm{C}=\mathrm{C}$ stretching or to the conjugated unsaturation structure ${ }^{7,8)}$. Peaks appearing at 29502700,1450 , and $1370 \mathrm{~cm}^{-1}$ were due to the alkyl groups substituted to aromatic compounds ${ }^{7,8)}$. Absorbance at $3650-3050 \mathrm{~cm}^{-1}$ was characteristic of hydroxyl or carboxyl groups ${ }^{8}$. Any peaks associated with such oxygen-containing groups were not observed in the IR spectrum of the original sample. These results imply that sediments comprised mainly of aromatic and naphthenic compounds with carbonyl, carboxyl, and hydroxyl groups. In addition, peaks relevant to nitrogen-containing groups were not detected in the IR spectrum of the original sample nor in that of the sediments. Thus, a low concentration of nitrogen compounds may be speculated in the original sample as well as in the sediments, although no elemental analysis was made in this study.

The results observed indicated that color degradation and formation of sediments by sunlight irradiation proceed via incorporation of oxygen into aromatic and naphthenic compounds in the sample, which was hydrotreated followed by dewaxing.

In preliminary experiments, a solution of toluene containing $1 \mathrm{wt} \%$ of benzo[a]pyrene was irradiated by sunlight. The relative transmittance of the solution

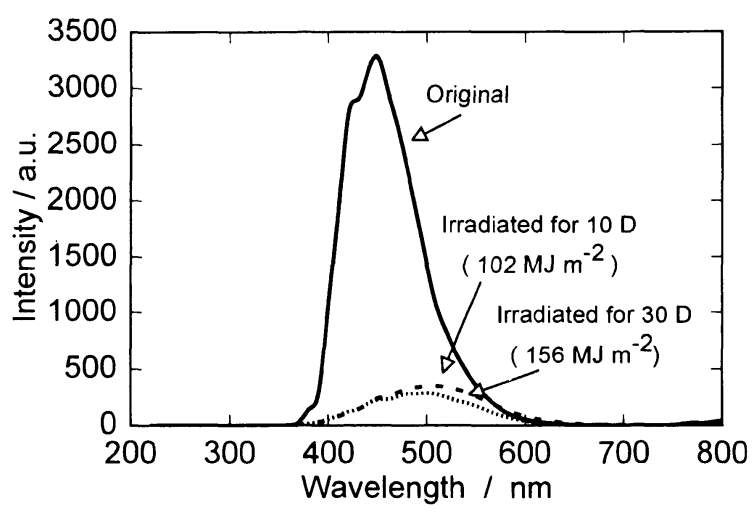

Numbers in parentheses indicate global solar radiation.

Fig. 4 Fluorescence Emission Spectra (excitation at $320 \mathrm{~nm}$ ) of the Sample before and after Irradiation

decreased to $25 \%$ and sediments were formed when the global solar radiation reached $c a .40 \mathrm{MJ} / \mathrm{m}^{2}$. The peaks assigned to $\mathrm{C}=\mathrm{O}$ and $\mathrm{C}-\mathrm{O}$ were detected in the IR spectrum of the sediments. No significant change in transmittance, however, was observed and no sediments were formed when the toluene in the solution was exposed to sunlight. Therefore, these facts strongly support the idea that photo-oxidation of such polynuclear aromatic hydrocarbon as benzo[a]pyrene is directly related to color degradation.

\section{3. 2. Change in Fluorescence Emission Spectra}

Figure 4 shows fluorescence spectra of sample oils. It is noticeable that the intensity of the peaks of the irradiated sample drastically decreased in comparison with that of the original oil, indicating that components that emit fluorescence spectra may be key species that cause color degradation by sunlight. Judging from the boiling range of the sample oil, higher alkenes or polynuclear aromatic compounds with three to five fused-rings may be the most feasible components of fluorescence spectra. Of these, polynuclear aromatic compounds, which are frequently formed during severe oil hydrotreating, are considered to be responsible for color instability ${ }^{6}$. Thus, it is highly likely that such compounds cause sediment formation in the oil.

\section{3. 3. Effect of Dissolved Oxygen in the Sample}

Oxygen is incorporated in the sediments as carboxylate, carbonyl, and hydroxy groups as discussed in 3. 3. 1. In order to elucidate the effect of dissolved oxygen, a degassed sample (sample II) was prepared, and color degradation behavior was compared with that of the original oil as received (sample I). Sample II was prepared by removing the dissolved oxygen (air) from the original oil by freeze-pumping and thawing, each repeated 6 times. Both samples were then exposed to sunlight under the same conditions. Neither a significant change in color nor a significant change in the formation of sediments was detected in sample II while the 
Table 2 Effect of Dissolved Oxygen on Color Degradation

\begin{tabular}{lccc}
\hline Sample & $\begin{array}{c}\text { Relative transmittance } \\
\left.\text { (global solar radiation }\left[\mathrm{MJ}^{2} \mathrm{~m}^{2}\right]\right)\end{array}$ & $\begin{array}{c}\text { Amount of sediment } \\
{[\mathrm{mg} / \mathrm{g} \text {-oil] }}\end{array}$ \\
\hline $\mathrm{I}^{\mathrm{a})}$ & $(0.0)$ & 100 & 0.0 \\
$\mathrm{I}^{\mathrm{a}}$ & $(156.4)$ & 57.4 & 0.31 \\
$\mathrm{I}^{\text {b) }}$ & $(0.0)$ & 100 & 0.0 \\
$\mathrm{II}^{\text {b) }}$ & $(208.1)$ & 71.2 & 0.0 \\
\hline
\end{tabular}

a) Sample I contained dissolved oxygen at the original level.

b) Dissolved oxygen was removed from Sample I by freeze-pumping and thawing.

change in color and formation of sediments were observed in sample I. This means that dissolved oxygen in the lubricating base oil is an essential element in color degradation due to sunlight irradiation. In the absence of oxygen, typical photochemical reactions of polynuclear aromatics are known to be isomerization and cycloaddition that lead to the formation of hydroaromatics and relevant isomers. These components may not be converted directly into sediments. In the presence of oxygen, however, the formation of peroxides of polynuclear aromatics proceeds. Then the decomposition of them, produces oxygen-containing groups such as carbonyl, carboxyl, and hydroxyl groups, which were observed in IR spectra of the sediments. Thus, both dissolved oxygen and polynuclear aromatics seem to be indispensable for inducing color degradation by photoirradiation.

\section{Conclusions}

(1) The color of the lubricating base oil turns from pale yellow to dark brown, and the amount of sediment formed increases with sunlight irradiation. The behavior of color degradation is different depending on the season of irradiation and on ambient temperature.

(2) It can be concluded that color degradation of lubricating base oils in the sunlight proceeds when the oils contain both dissolved oxygen and fluorescent components such as polynuclear aromatics.

\section{References}

1) Nelson, W. L., "Petroleum Refinery Engineering," 4th Ed., McGraw-Hill, N.Y. (1958).

2) Hattori, S., PETROTECH, 4, (11), 1025 (1981).

3) Hydrocarbon Processing, 73, (11), 85 (1994).

4) Matsunaga, A., Ph. D. Thesis, Kyoto University, Kyoto, Japan, 1982.

5) Takatsuka, T., Wada, Y., Suzuki, H., Komatsu, S., Morimura, Y., Sekiyu Gakkaishi, 35, (2), 179 (1992).

6) Bhan, O. K., Brinkman, D. W., Green, J. B., Carley, B., Fuel, 66, (9), 1200 (1986).

7) Power, A. J., Fuel, 65, (1), 133 (1986); Hazlett, R. N., Power, A. J., Fuel, 68, (9), 1112 (1989).

8) Pedley, J. F., Hiley, R. W., Hankock, R. A., Fuel, 66, (12), 1646 (1987). 
要 旨

\section{日光照射により誘起される潤滑油基油の色相劣化}

進藤 隆世志，堀部 英司，北林 茂明，小沢 泉太郎

秋田大学工学資源学部環境物質工学科, 010-8502 秋田市手形学園町 1-1

日光照射による潤滑油基油の色相劣化の挙動を UV-vis, FTIR および蛍光分光分析法を用いて検討した。日光照射に伴い, 試料油の色相は淡黄色から濃褐色に変化し, 沈積物の量が増大 した。色相変化の挙動は, 日光照射の季節すなわち, 照射光の 波長とその強度分布, 照射の際の温度に依存して変化した。未 照射の試料油に比べて, 日光照射油の蛍光スペクトルの強度が 減少したことから，色相劣化の原因物質は蛍光を示す 3 ないし
5 環の縮合多環芳香族成分であることが示唆される。光照射中 に形成された沈積物は, 主としてカルボニル基, カルボキシル 基および水酸基を有する芳香族で構成されていた。脱気をしな いもともとの試料油の場合には色相変化や沈積物の生成が観測 されたが，脱気した試料油の場合には色相変化や沈積物は確認 されなかった。試料油中の溶存酸素と多環芳香族はいずれも光 によって誘発される色相劣化に不可欠であると結論される。

\section{Keywords}

Lubricant, Polynuclear aromatics, Color degradation, Photo oxidation 